\title{
The Effects of Spiritual Care on Depression and Meaning in Life in the Clients with Kidney Failure Receiving Hemodialysis in Rumah Sakit Islam Surabaya
}

\author{
Lono Wijayanti ${ }^{1}$, Joni Haryanto ${ }^{2}$, Suharto $^{3}$ \\ ${ }^{1}$ Master of Nursing Student, Faculty of Nursing, Universitas Airlangga, Surabaya, East Java 60115, Indonesia \\ ${ }^{2,3}$ Faculty of Nursing, Universitas Airlangga, Surabaya, East Java 60115, Indonesia
}

\begin{abstract}
Introduction: Depression often happens to clients with terminal and chronic diseases which causes them to lose the meaning in life. This research was purposed to identify the effects of spiritual care on the level of depression and the meaning in life of the clients with hemodialysis. Methods: This research used quasi-experimental design, done using pretest-posttest control group design. The population of all clients with hemodialysis found in RS Islam Surabaya, totaling 34 people, divided into two groups taken by using total sampling technique. Questionnaires used in this research were BDI and MLQ. The data were analyzed using Wilcoxon signed-rank test and MannWhitney test. Results and analysis: The research showed that Wilcoxon signed-rank test before and after receiving spiritual care, there was a significant difference in the level of depression in both groups in which $\rho=0.000$ was found in treatment group. The meaning in life showed a significant result in which $\rho=0.001$ in treatment group. Mann-Whitney test on the level of depression and the meaning in life showed that $\rho=0.000$. Discussion and conclusion: Spiritual care has positive effects to decrease depression and to increase the meaning in life possessed by the clients with hemodialysis.
\end{abstract}

Keywords: Spiritual care, depression, meaning in life

\section{Introduction}

Clients receiving hemodialysis often experience depression and meaningless life. Depression is a common mental disorder generally found in the clients suffering from kidney failure receiving hemodialysis (Hedayati et al., 2009). The main psychological problem of those clients is depression in which its symptoms get worse from time to time (Kiosses, 2012; Bossola et al., 2012). Approximately $40 \%$ of the clients with terminal kidney failure have depression. The percentage increases up to $50 \%$ when they receive hemodialysis (Pace, 2007), so they need psychosocial and spiritual nursing care.

Terminal kidney failure is the highest stage of irreversible chronic kidney failure. Clients must follow the therapy to substitute the functions of kidney by receiving hemodialysis to survive. In Asian countries, $12.5 \%$ has terminal or chronic kidney failure. In Japan, terminal kidney failure is suffered by more than 2.000 people (Iseki, 2009). The condition of comorbidity which is progressing in insufficiency renal chronic contributes to the increasing rate of morbidity and mortality of clients with terminal kidney failure (Wijaya, 2005; Smeltzer, 2008).

In Indonesia, 59\% of diseases is caused by non-contagious diseases which need a very high amount of money for medication. One of them is terminal kidney failure. Indonesia is the country where the incidence rate of kidney failure is high enough. It increases up to $20 \%$ in Indonesia (Balitbangkes, 2010).

The prevalence rate of depression shows that the incidence rate of depression in clients receiving hemodialysis varies, ranging from minimum depression $21.43 \%$, mild depression $35.71 \%$, moderate depression $17.85 \%$, to severe depression $14.28 \%$ (Bossola et al, 2012). The result of research done in RSUP Fatmawati Jakarta in the context of nursing care showed that the clients with kidney failure receiving hemodialysis had emotional reaction, such as helplessness, sadness, anger, fear, and guilty feeling. Moreover, when they were diagnosed with chronic kidney failure, they felt confused with what to do, cried, and felt isolated (Farida, 2010).

Spiritual intervention is believed to be able to decrease depression optimally because the clients can do this inexpensive and non-toxic intervention independently any time and any place. Good spirituality closely relates with the low score of depression (Bormann, 2005; Bekelmann, et al, 2007).

The relationship between humans and God is the first element in spirituality. The coping strategy often applied by clients to overcome stress resulting from the disease they are suffering is to get close to their God. The spiritual power of the clients can be the important factor to face changes caused by chronic diseases. Besides, the spiritual components also cover the relationship between humans and nature, humans and

Volume 6 Issue 7, July 2017 


\section{International Journal of Science and Research (IJSR) \\ ISSN (Online): 2319-7064 \\ Index Copernicus Value (2015): 78.96 | Impact Factor (2015): 6.391}

themselves, humans and other humans. (Dossey \& Keegan, 2015).

The spiritual interventions to overcome depression are shukr breathing (thankful breathing to Allah) and dhikr (remembrance of Allah). Nurses can use them as the stimulus to handle depression through shukr breathing, suggesting their clients to do relaxation by deeply inhaling while thanking Allah for the blessings in life. In addition, the relaxation technique can effectively decrease and prevent the psychological effects of stress (John, 2013; Mahdavi et al, 2013; Catherine \& King, 2013).

Spiritual care through shukr breathing and $d h i k r$ causes the clients' spirituality to increase and the soul to be peaceful in order to grow adaptive behaviors to decrease the level of depression, which eventually results in homeostasis (balanced) process. All protective elements available in the human's body work based on the obedience in worshiping God, getting close to and thanking Allah SWT that finally creates the balance in neurotransmitter in the brain (Saleh, 2010; Zainul, 2007; Yamamoto \& Nagata, 2011).

Nurses play very important roles in providing nursing care for the clients receiving hemodialysis by focusing the nursing care on the clients' needs for health holistically covering the efforts to bring the emotional, spiritual, and social health back to normal. In line with Calista Roy's statement that the purpose of nursing care is to increase the responses which can be achieved by performing the six steps of nursing process, namely: behavior assessment, stimulus assessment, nursing diagnosis, outcome identification, intervention, and adaptive evaluation.

\section{Method}

This research used quasi-experimental design, done using pretest-posttest control group design. It involved two groups of subject: treatment and control group. It was done in hemodialysis room of RS. Islam Surabaya. This research involved the population of all clients with terminal kidney failure receiving hemodialysis. The number of clients receiving hemodialysis was 34 people divided into two groups, namely 17 people in control group and 17 people in treatment group. The samples were taken using total sampling technique. The instrument used in this research to measure the level of depression was the Beck Depression Inventory (BDI), whereas The Meaning in Life Questionnaire (MLQ) was used to measure the ability to give meaning to life. Those instruments are in the form of questionnaires. The data were analyzed using Wilcoxon signed-rank test and Mann-Whitney test.

\section{Result}

a) Descriptive analysis

1) Sex

Table 1: The Frequency Distribution of The Respondents Based on Sex

\begin{tabular}{|l|c|c|c|c|}
\hline \multirow{2}{*}{ Variable } & \multicolumn{2}{|c|}{ Treatment } & \multicolumn{2}{c|}{ Control } \\
\cline { 3 - 6 } & $\mathbf{n}$ & $\mathbf{\%}$ & $\mathbf{n}$ & $\boldsymbol{\%}$ \\
\hline 1) Male & 11 & 64,7 & 13 & 76,5 \\
\hline 2) Female & 6 & 35,3 & 4 & 23,5 \\
\hline Total & $\mathbf{1 7}$ & $\mathbf{1 0 0}$ & $\mathbf{1 7}$ & $\mathbf{1 0 0}$ \\
\hline
\end{tabular}

Source: Primary Data in 2017

According to table 1 , the result of equivalence test using Pearson's Chi-square Test was $\rho(0.708)>\alpha(0.05)$. It showed that there was no characteristic difference of sex in both groups.

2) Age

Table 2: The Frequency Distribution of The Respondents Based on Age

\begin{tabular}{|c|c|c|c|c|}
\hline \multirow{2}{*}{ Variable } & \multicolumn{2}{|c|}{ Treatment } & \multicolumn{2}{|c|}{ Control } \\
\hline & $\mathbf{n}$ & $\%$ & $\bar{n}$ & $\%$ \\
\hline 1) $30-45$ & 1 & 5,9 & 2 & 11,8 \\
\hline 2) $46-60$ & 11 & 64,7 & 11 & 64,7 \\
\hline 3) $>60$ & 5 & 29,4 & 4 & 23,5 \\
\hline Total & 17 & 100 & 17 & 100 \\
\hline
\end{tabular}

Source: Primary Data in 2017

Based on table 2, the result of equivalence test using Fischer's Exact Test showed that $\rho(1.000)>\alpha(0.05)$. It illustrated that there was no characteristic difference of age in both groups.

\section{3) Level of Education}

Table 3: The Frequency Distribution of The Respondents Based on Level of Education

\begin{tabular}{|ll|c|c|c|c|}
\hline \multirow{2}{*}{ Variable } & \multicolumn{2}{|c|}{ Treatment } & \multicolumn{2}{c|}{ Control } \\
\cline { 3 - 6 } & n & $\mathbf{( \% )}$ & $\mathbf{n}$ & $\mathbf{\%}$ \\
\hline 1) & Elementary school & 1 & 5,9 & 0 & 0 \\
\hline 2) & Junior high school & 2 & 11,8 & 2 & 11,8 \\
\hline 3) & Senior high school & 10 & 58,8 & 8 & 47,1 \\
\hline 4) & College & 4 & 23,5 & 7 & 41,2 \\
\hline \multicolumn{2}{|l|}{ Total } & $\mathbf{1 7}$ & $\mathbf{1 0 0}$ & $\mathbf{1 7}$ & $\mathbf{1 0 0}$ \\
\hline
\end{tabular}

Source: Primary Data in 2017

Table 3 shows the result of equivalence test using Fischer's Exact Test in which $\rho(0.704)>\alpha(0.05)$. It revealed that there was no characteristic difference of level of education in both groups.

\section{4) Marital Status}

Table 4: The Frequency Distribution of The Respondents Based on Marital Status

\begin{tabular}{|c|c|c|c|c|}
\hline \multirow{2}{*}{ Variable } & \multicolumn{2}{|c|}{ Treatment } & \multicolumn{2}{|c|}{ Control } \\
\hline & $\mathbf{n}$ & $(\%)$ & $\mathbf{n}$ & $\%$ \\
\hline 1) $\mathrm{Mar}$ & 16 & 94,1 & 17 & 100 \\
\hline 2) Unn & 1 & 5,9 & 0 & 0 \\
\hline Total & 17 & 100 & 17 & 100 \\
\hline
\end{tabular}

Source: Primary Data in 2017 


\section{International Journal of Science and Research (IJSR) \\ ISSN (Online): 2319-7064 \\ Index Copernicus Value (2015): 78.96 | Impact Factor (2015): 6.391}

Table 4 illustrating the result of equivalence test using Pearson's Chi-square Test showed that $\rho(1.000)>\alpha(0.05)$. It showed that there was no characteristic difference of marital status in both groups.

\section{5) Sleep Pattern}

Table 5: The Frequency Distribution of The Respondents Based on Sleep Pattern

\begin{tabular}{|c|c|c|c|c|}
\hline \multirow{2}{*}{ Variable } & \multicolumn{2}{|c|}{ Treatment } & \multicolumn{2}{|c|}{ Control } \\
\hline & n & $(\%)$ & $\mathbf{n}$ & $\%$ \\
\hline 1) Sleeping tight & 2 & 11,8 & 0 & 0 \\
\hline 2) Often waking up while sleeping & 5 & 29,4 & 11 & 64,7 \\
\hline 3) Unable to sleep & 10 & 58,8 & 6 & 35,3 \\
\hline Total & 17 & 100 & 17 & 100 \\
\hline
\end{tabular}

Source: Primary Data in 2017

Table 5 shows the result of equivalence test using Fischer's Exact Test in which $\rho(0.082)>\alpha(0.05)$. It proved that there was no characteristic difference of sleep pattern in both groups.

\section{b) Bivariate analysis}

1) The Effects of Spiritual Care on The Level of Depression

Table 6: The Effects of Spiritual Care on The Level of

$$
\text { Depression }
$$

\begin{tabular}{|c|c|c|c|c|}
\hline Group & $n$ & Variable & $Z$ & $P$ \\
\hline Treatment & 17 & $\begin{array}{c}\text { Depression Pre-test } \\
\text { Depression Post-test }\end{array}$ & $-4,123$ & 0.000 \\
\hline Control & 17 & $\begin{array}{c}\text { Depression Pre-test } \\
\text { Depression Post-test }\end{array}$ & 0,000 & 1,000 \\
\hline
\end{tabular}

Source: Primary Data in 2017

According to table 6 , the result shown by Wilcoxon signedrank test illustrated that the significance value $\rho=0.000$ in the treatment group. It showed that there was a difference of depression level before and after receiving spiritual care. Whilst, $\rho=1.000$ in the control group showing that there was no difference of depression level in the clients receiving hemodialysis before and after receiving standard therapy in the hemodialysis room.

\section{2) The Effects of Spiritual Care on The Meaning in Life}

Table 7: The Effects of Spiritual Care on The Meaning in Life

\begin{tabular}{|c|c|c|c|c|}
\hline Group & $\mathrm{n}$ & Variable & $\mathrm{Z}$ & $P$ \\
\hline Treatment & 17 & $\begin{array}{c}\text { Meaning in life Pre-test } \\
\text { Meaning in life Post-test }\end{array}$ & -3.317 & 0.001 \\
\hline Control & 17 & $\begin{array}{c}\text { Meaning in life Pre-test } \\
\text { Meaning in life Post-test }\end{array}$ & 1.000 & 0.317 \\
\hline
\end{tabular}

Source: Primary Data in 2017

Table 7 which describes the result of analysis using Wilcoxon signed-rank test illustrated that the significance value $\rho=0.001$ in the treatment group. It showed that there was a difference of the meaning in life before and after receiving spiritual care. Whilst, $\rho=0.317$ in the control group illustrating that there was no difference of the meaning in life in the clients receiving hemodialysis before and after receiving standard therapy in the hemodialysis room.

\section{3) The Difference of Depression Level in The Treatment and Control Group}

Table 8: The Difference of Depression Level

\begin{tabular}{|c|c|c|c|}
\hline Variable & Amount & $\rho$ value & $Z$ \\
\hline Treatment & 17 & \multirow{2}{*}{0,000} & $-5,351$ \\
\hline Control & 17 & & \\
\hline
\end{tabular}

Source: Primary Data in 2017

Based on table 8, the result of Mann-Whitney test showed that $\rho=0.000(<0.05)$ illustrating that there was a significant difference of the decrease in depression level between the treatment and control group.

\section{4) The Difference of The Meaning in Life in The} Treatment and Control Group

Table 9: The Difference of The Meaning in Life

\begin{tabular}{|c|c|c|c|}
\hline Variable & Amount & $\rho$ value & $Z$ \\
\hline Treatment & 17 & & $-3,536$ \\
\hline Control & 17 & 0,000 & \\
\hline
\end{tabular}

Source: Primary Data in 2017

According to table 9, the result of Mann-Whitney test showed that $\rho=0.000(<0.05)$ illustrating that there was a significant difference in the increasing ability to give meaning in life between the treatment and control group.

\section{6) Discussion}

\section{Descriptive Analysis}

\section{a) Sex}

The result of this research showed that $64.7 \%$ of the respondents in the treatment group were males, whereas $76.5 \%$ in the control group were females. In line with the research conducted by Istanti (2009) in RSU PKU Muhammadiyah, it revealed that $62.5 \%$ of the respondents with kidney failure receiving hemodialysis were males. In addition, Manzilah through her research (2011) done in RS Hospital Cinere Depok explained that $60 \%$ of the respondents were also males.

Based on research, males and females have the same risk to experience depression However, it mostly happens to males because of their roles in the family as both the leader and the backbone of the family. If a man suffering from terminal kidney failure must receive hemodialysis treatment for the rest of his life, he might feel useless because of his inability to do his functions and roles in his family.

b) Age

Based on the result of the research, $64.7 \%$ of the respondents suffering from kidney failure with hemodialysis were 46-60 


\section{International Journal of Science and Research (IJSR) \\ ISSN (Online): 2319-7064 \\ Index Copernicus Value (2015): 78.96 | Impact Factor (2015): 6.391}

years old in the treatment and the control group. The age of 46-60 is the early and late stage of elderly (Department of Health, 2009).

The same result obtained from the research done by Cahyu (2013) in RS Prof. Dr. Margono Soekarjo Purwokerto exposing that the respondents receiving hemodialysis were approximately 50.4 years old, ranging from 25 years old (the youngest ) to 75 years old (the oldest).. Suryariningsih's research (2010) described that the approximate age of the clients with hemodialysis in RS Padang was 48,65 years old, ranging from 19 years old (the youngest) to 68 years old (the oldest).

At the age of 40-70, glomerular filtration rate (GFR) decreases progressively down to $50 \%$ from normal; the ability of kidney tubules to reabsorb dark urine also decreases; the ability to empty the bladder perfectly decreases so that the risks of infection and obstruction increase; and the decreased fluid intake which might be the risk factor for kidney damage (Brunner \& Suddart, 2002).

The researcher claims that age development gives more effects to the decrease in the clients' physical ability. The results of interview and observation showed that the respondents could not do their activities optimally so that they could not work effectively because of tiredness. It absolutely brings the great effects to the financial condition in spite of the health insurance (BPJS). The productivity and creativity also decrease because they have to leave their work for hemodialysis treatment twice a week. Therefore, the clients with terminal kidney failure receiving hemodialysis experience depression

\section{c) Level of education}

This research found out that $58.8 \%$ of the respondents in the treatment group and $47.1 \%$ in the control group graduated from senior high school. In line with the research conducted by Manzilah (2011), among 40 respondents with chronic kidney failure receiving hemodialysis in RS Hospita Cinere Depok, most of them totaling 29 respondents $(72,5 \%)$ graduated from senior high school.

The researcher argues that the level of education of the clients affects their interest to obtain information about terminal kidney failure with hemodialysis. Moreover, more knowledge about their problem will cause them to have more worries, scare, and depression knowing that their problem has no cure.

This fact is not supported by the theory stating that the low level of knowledge causes more worries, scare, and depression. Thus, the high level of knowledge affects the mindset (Stuart, 2009).

\section{d) Marital status}

Based on the result of this research, $94.1 \%$ of the respondents in the treatment group and $100 \%$ in the control group were married. The research conducted by Kristianingsih (2008) and Slametiningsih (2012) stating that most of the clients with kidney failure receiving hemodialysis in RS Fatmawati and RS Islam Cempaka Putih Jakarta Pusat were married supported the result.

Marriage can be a positive aspect to receive the great social supports; in contrast, it can be a negative aspect if the marriage has conflicts. The spouse likely experiences changes in his/her normal functions in the family. For instance, a person functioning as the caregiver for his/her sick spouse will become an object of anger expressed by the sick. This condition may cause mental disturbances, such as depression that eventually results in unhappy marriage. $25 \%$ of the spouses of the clients with hemodialysis experienced depression as reported in the research conducted in Canada (Cukor et al, 2007).

\section{e) Sleep pattern}

Based on the result of this research, 58.8\% of the respondents in the treatment group complained of having inability to sleep, whereas $64.7 \%$ in the control group woke up frequently. This research assumes that some psychological and biological factors affect the sleep pattern of the clients receiving hemodialysis.

According to the result of this research, the clients with terminal kidney failure receiving hemodialysis often experienced sleep pattern disturbances despite the duration of illness. Another research illustrating that the high level of insomnia experienced by the clients receiving a long-term hemodialysis treatment had a correlation with the more progressive symptoms and the disease that needs dialysis therapy, or the complications such as cardiovascular and neurological problems often found in the clients receiving a long-term hemodialysis (Sabbatini et al, 2002). This result was also supported by other studies stating that the clients receiving a long-term hemodialysis generally had physical and social deficits as well as decreasing mental health, like depression. (Coccossis et al, 2008).

\section{f) Bivariate Analysis}

The result of this research showed significant differences of the level of depression and the meaning in life in both groups after receiving spiritual care through shukr breathing and $d h i k r$. The treatment group experienced a decrease in the level of depression and an increase in the meaning in life. In contrast, the control group did not have any changes in the level of depression and the meaning in life.

Based on Roy's adaptation theory, the researcher assumes that the nursing care done by nurses is aimed to increase the clients' adaptive responses by manipulating external contextual stimulus (spiritual care) through relaxation exercise of $s h u k r$ breathing and $d h i k r$ done repeatedly.

Relaxation exercise of shukr breathing and dhikr done repeatedly will influence cognator and regulator subsystem. Shukr breathing cause oxygen to flow in the blood vessels and other body tissues, remove toxins and metabolic wastes so that the body condition will be relaxed. During relaxation, dhikr 


\section{International Journal of Science and Research (IJSR) \\ ISSN (Online): 2319-7064 \\ Index Copernicus Value (2015): 78.96 | Impact Factor (2015): 6.391}

should be recited repeatedly. The repeated $d h i k r$ is a part of cognator process aimed to focus the mind on the meaning of dhikr phrases which contain positive meanings. By reciting dhikr, a human eternalizes the characteristics and names of Allah that contain a very remarkable power. Hence, spiritual power creates peace and a balance in emotion.

Dhikr phrases used as the spiritual care (external contextual stimulus) are Astaghfirullahal'adzim, Subhanallah, and Alhamdulillah which refer to the sincerity of asking for God's forgiveness which will make someone feel stronger to face problems, such as complications of disease and death. Reciting Dhikr is also the manifestation of surrender to God which will result in hopes and positive thoughts in life as well as peaceful soul (Newberg\&Waldman, 2013); it is also an expression of gratitude to God. Thanking God leads a person to have positive thoughts all the time, to see something in positive perspectives, to give positive meaning to any events, and to be patient when facing problems (Suryani, 2015).

Saying positive words or sentences is believed to result in positive thoughts and emotion. (Newberg\&Waldman, 2013). This condition is very useful to increase the production of endorphin melatonin and serotonin, as well as to decrease cortisol, the stress hormone (Alam \& Hadibroto, 2017).

Endorphin is a hormone that triggers happiness, whereas melatonin can increase the quality of sleep so that the body can produce the natural healing, the so-called Human Growth Hormone (HGH) (Alam \& Hadibroto, 2017). The functions of HGH are as follows: to provide energy (for vitality), to maintain stamina, to increase the quality of sleep, to provide comfortable feeling, and to relieve anxiety. Furthermore, serotonin affects the mood, sexual desire, sleep, memory, temperature regulation, and social characteristics (Alam \& Hadibroto, 2007).

Spiritual care is a therapy which can be applied to decrease the level of depression and increase the ability to give meaning in life. It is supported by the previous research claiming that the high level in the meaning in life decreases the risks for depression. Moreover, the meaning in life is a concept cognitively understood by individuals in which things happening in life results in the decrease in depression. (Hedayati, 2009; Prihastiwi, 1994; Kleftaras \& Psarra, 2012).

\section{Conclusion}

The respondents receiving spiritual care through the relaxation of shukr breathing and dhikr experience the decrease in depression level and the increase in giving meaning to their lives as compared with the respondents receiving no spiritual care through the relaxation of shukr breathing and dhikr.

The clients with terminal kidney failure receiving hemodialysis should do spiritual care through shukr breathing and $d h i k r$ daily.

\section{References}

[1] Alam, S.,\& Hadibroto, L., 2007. Gagal Ginjal. Jakarta: Gramedia

[2] Badan Penelitian dan Pengembangan, 2010. Riset Kesehatan Dasar (RISKESDAS)., pp.1-111.

[3] Bekelman David B., Sydney M. Dy, Diane M. Becker, Ilan S. Wittstein, Danetta E. Hendricks, Traci E. Yamashita, S.H.G., 2007. Spiritual well-being and depression in patients with heart failure. Journal of General Internal Medicine, 22(4), pp.470-477.

[4] Bossola Maurizio, Claudia Ciciarelli, Enrico Di Stasio, Gian Luigi Conte, Manuela Antocicco, Fausto Rosa, L.T., 2012. Symptoms of depression and anxiety over time in chronic hemodialysis patients. Journal of Nephrology, 25(5), pp.689-698.

[5] Bormann, J.E., 2005. Frequent, silent mantram repetition: A Jacuzzi for the mind. Advanced Emergency Nursing Journal, 27(Topics in Emergency Medicine), pp.163-166.

[6] Brunner\&Suddart, S., 2002. Buku Ajar Keperawatan Medikal Bedah Alih Bahasa Hartono, dkk, Jakarta.

[7] Cahyu Septiwi, 2013. Pengaruh Breathing Exercise Terhadap Level fatigue Pasien Hemodialisis di RSPAD Gatot Subroto Jakarta. Jurnal Keperawatan Soedirman, 8(1), pp.14-21.

[8] Catherine \& King, J., 2013. Problem Solved Anxiety Prevention. , 65 (11), p.62.

[9] Coccossis, M.G., Theofilou, P., Synodinou, C., Tomaras, V., Soldatos, C. 2008. Quality of Life, Mental Health nd Health Beliefs in Hemodialysis Patients and Peritoneal Dialysis Patients: Investigating Differences in Early and Later Years of Currens Treatments. BMC Nephrols; 9:14.

[10] Cukor Daniel, Jeremy Coplan, Clinton Brown, Steven Friedman, Allyson Cromwell-Smith, Rolf A. Peterson, P.L.K., 2007. Depression and anxiety in urban hemodialysis patients. Clinical Journal of the American Society of Nephrology, 2(3), pp.484-490.

[11] Dossey, Barbara Montgomery \& Keegan, L., 2015. Holistic Nursing: A Handbook for Practice 7th ed. K. M. A. Cynthia C. Barrere, Mary A. Blaszko Helming, Deborah A. Shields, ed., Burlington: Jones \& Bartlett Learning.

[12] Farida Ana, 2010. Pengalaman klien hemodialisa terhadap kualitas hidup dalam konteks asuhan keperawatan Di RSUP Fatmawati Jakarta. Available at: http:/lontar.ui.ac.id/ tanggal 10 Oktober 2016.

[13] Hedayati, S.S. \& Finkelstein, F.O., 2009. Epidemiology, diagnosis, and management of depression in patients with CKD. American journal of kidney diseases: the official journal of the National Kidney Foundation, 54(4), pp.741-52.

[14] Iseki, 2009. Prevalensi ESRD meningkat saat ini. Jurnalckd-cronic-disease-kidney.

[15] Istanti, Y.P, 2009. Faktor yang Berkontribusi Terjadinya IDWG pada Kien Yang Menjalani Hemodialisa di RSU PKU Muhammadiyah Yogyakarta. http/lontar.ui.ac.id/file=digital/125543- 


\section{International Journal of Science and Research (IJSR) \\ ISSN (Online): 2319-7064}

Index Copernicus Value (2015): 78.96 | Impact Factor (2015): 6.391

TESIS580\%20N09f-Faktor-faktor-HA.pdf diakses tanggal 21 April 2017

[16] John, D., \& Gregory, F., 2013. The development of a patient-centered program based on the relaxation response: The relaxation response resiliency program (3RP). Psychosomatics, 54, pp.165-174.

[17] Kallenbach, J.Z., Gutch, CF. Stoner, M.H, Corea, A.L., 2005. Review of Hemodialysis for Nurses and Dialysis Personal edisi 7., St Louis: Elsevier Mosby.

[18] Kleftaras, G., \& Psarra, E., 2012 Meaning in Life, Psychological Well-Being and Depressive Symptomatology: A Comparative Research. Scentific Research Journal. Vol.3. No.4. P 337-345.

[19] Kiosses, Vasilios; Karathanos, V., 2012. Depression in Patients with CKD: A Person Centered Approach. Journal of Psychology \& Psychotherapy, S3(1).

[20] Mahdavi Ali, Mohammad Ali Heidari Gorji, Ali Morad Heidari Gorji, Jamshid Yazdani, M.D.A., 2013. Implementing Benson's relaxation training in hemodialysis patients: Changes in perceived stress, anxiety, and depression. North American Journal of Medical Sciences, 5(9), pp.536-540.

[21] Mahmoud, M.A., 2008. Drug Therapy Problems and Quality of Life in Patient with Chronic Kidney Disease. Thesis. University Sains Malaysia

[22] Manocha, R., 2014. Silence Your Mind: Improve Your Happiness in Just 10 Minutes a Day with This New Approach to Meditation, Sydney: Hachette.

[23] Manzilah,T.,2011. Faktor yang Mempengaruhi Terjadinya Infeksi Double Lumen pada Klien Hemodialisa Di Rumah Sakit Hospital Cinere Depok Tahun

2011.http://www.libary.upnvj.ac.id/pdf/3keperawatanpdf /0910712026bab6.pdf diakses tanggal 21 April 2017

[24] Newberg, A., \& Waldman, M., 2013. Born To Believe: Gen Iman dalam Otak. (Alih Bahasa Nukman, E.F). Bandung:Mizan

[25] Pace, R.C., 2007. Fluid Management in Patient on Hemodialysis. Nephrology Nursing Journal, 34(5), p.557.

[26] Prihastiwi. W.J., 1994. Kebermaknaan Hidup Lanjut Usia Pensiun Dikaitkan dengan Tingkah Laku Koping, Religiusitas surabaya. Naskah Publikasi (tidak diterbitkan). Program Pasca Sarjana UGM. Yogyakarta.

[27] Sabbtini, M., Minale, B., Crispo, A., et al. 2002. Insomnia in Maintenance Hemodialysis Patients. Nephrology Dialysis Transplantation 17: 852-856. http://ndt.oxfordjournals.org/cgi/content/short/17/5/852.

[28] Saleh, A.Y., 2010. Berdzikir untuk Kesehatan Syaraf, Jakarta: Zaman.

[29] Smeltzer, S.C., \& Bare, B., 2002. Keperawatan Medikal Bedah Bruner \& Suddarth Ed. 8. Alih Bahasa Pakaryaningsih E. M., ed., Jakarta: EGC.

[30] Smeltzer S.C., B. G. Bare, J. L. Hinkle, K.H.C., 2008. Textbook of medical-surgical nursing ed 12., Philadelpia: Lippincott William \& Wilkins.

[31] Stuart. 2009. Princip and Practice of Psychiatric Nursing. (9 th ed). Mosby louis. Missouri.

[32] Suryani, \& A.I., 2015. Pengaruh Relaksasi Dzikir terhadap Tingkat Kecemasan Pasien Gagal Ginjal Kronis yang Menjalani Hemodialisa The Impact of Dzikir to The Level of Anxiety of Chronic Renal Failure Patient Undergoing Hemodialysis. Jurnal keperawatan padjajaran, 3(January 2016).

[33] Suryarinilsih, Y.,2010. Hubungan Peningkatan Berat Badan antara Waktu Hemodialisis dengan Kualitas Hidup Klien Hemodialisis. Tesis.

[34] Wijaya, A., 2005. Kualitas hidup pasien penyakit ginjal kronik yang menjalani Hemodialsis dan mengalami deperesi. Perpustakaan Universitas Indonesia.

[35] Yamamoto K, N.S., 2011. Physiological and psychological evaluation of the wrapped warm footbath as a complementary nursing therapy to induce relaxation in hospitalized patients with incurable cancer: A pilot research. Cancer Nurs, (May-Jun;34(3)), p.185-92.

[36] Zainul, Z., 2007. Hidup Sehat Dengan Olah Lahir, Fikir, \& Zikir, Jakarta: Qultummedia. 